\title{
INVESTIGATION THE PROCESS OF FERMENTATION OF PUMPKIN PULP
}

\author{
V. Gnitsevych, Y. Honchar
}

Kyiv National University of Trade and Economics

\begin{tabular}{l}
\multicolumn{1}{c}{ Key words: } \\
Pumpkin pulp \\
Temperature \\
Time \\
Microbial origin enzyme \\
Pectin \\
\hline \multicolumn{1}{c}{ Article history: } \\
Received 14.03.2018 \\
Received in revised form \\
04.04.2018 \\
Accepted 16.04.2018 \\
\hline
\end{tabular}

Corresponding author:

V. Gnitsevych

E-mail:

flamber1965@gmail.com

\begin{abstract}
The article deals with the problem of processing secondary vegetable raw materials, for example, pulp of the pumpkin, which remains after the selection of seeds from the pumpkin. The author analyzes literary sources and scientific works on the issue of complete processing of the pumpkin. The expediency of the application of the fermentation process to the plant material - of the pumpkin pulp is justified. To activate the enzyme process, it is proposed to use the enzyme preparation Vetom 1.1 of the directed action produced by the microorganisms of the genus Bacillus subtilis. The object of the study was pumpkin, named nutmeg or Cucurbita moschata Duch of the botanic sort of Butternut.

The kinetics of the fermentolysis of soluble pectin substances of pumpkin pulp under the influence of the enzyme preparation Vetom 1.1, which has a directed effect, is investigated depending on the influence of technological factors. In particular, the dependence of the intensity of growth of the content of SP (soluble pectin) on temperature regimes and the duration of storage of pumpkin has been analyzed. It was established that according to the stable technological processing parameters, the content of SP (soluble pectin) in samples of pumpkin pulp, which were stored at low temperatures, was lower by $40-47 \%$, than when they were stored at $+8 \ldots+10^{\circ} \mathrm{C}$. In the article it was investigated how the temperature parameter, the heat treatment time of pumpkin pulp and the concentration of enzyme preparation of the directional action influence on the dynamics of accumulation of soluble pectin during the fermentation process. It is proved that the rational conditions of the process are: $\mathrm{t}=55 \pm 3^{\circ} \mathrm{C}, \tau=15$ hours, and the concentration of the enzyme preparation is $1,5 \%$ of the weight of the puree of the pumpkin pulp. The reccomendations about the use of the fermented puree of the pumpkin pulp are given, to include semi-finished products to products with high content of pectin.
\end{abstract}

DOI: $10.24263 / 2225-2924-2018-24-2-24$ 


\section{ДОСЛІДЖЕННЯ ПРОЦЕСУ ФЕРМЕНТОЛІЗУ М'ЯКОТІ ГАРБУЗА}

\section{В.А. Гніцевич, Ю.М. Гончар \\ Київський національний торговельно-економічний університет}

У статті досліджено проблему переробки вторинної рослинної сировини на прикладі м'якоті гарбуза, яка залишається після вибирання насіння із плоду. Проаналізовано літературні джерела та наукові прачі з питання повної переробки гарбуза. Обтрунтовано доцільність застосування процесу ферментування до рослинної сировини - м'якоті гарбуза. Для активації прочесу ферментолізу запропоновано застосування ферментного препарату Ветом 1.1 спрямованої діï, продукованого мікроорганізмами роду Bacillus subtilis.

Об'єктом дослідження було обрано гарбуз мускатний - Cucurbita moschata Duch. столового сорту Баттернат (Butternut).

Досліджено кінетику ферментолізу пектинових речовин м'якоті гарбуза під дією ферментного препарату спрямованої дії Ветом 1.1 залежно від впливу технологічних факторів. Зокрема, проаналізовано залежність інтенсивності зростання вмісту РП (розчинного пектину) від температурних режимів і тривалості зберігання плодів гарбуза. Встановлено, щзо за сталих технологічних параметрів обробки вміст РП (розчинного пектину) у зразків м'якоті гарбуза, які підлягали зберіганню за низьких температур, нижчий результуючий вміст пектинових речовин на 40-47\%, ніж при зберіганні його за $+8 \ldots+10^{\circ} \mathrm{C}$. 3 'ясовано, як впливає на перебіг процесу зміна температури, часу термічної обробки м'якоті гарбуза та концентрації внесеного ферментного препарату спрямованої дії на динаміку накопичення пектину. Доведено, щзо ращіональними умовами перебігу процесу $\epsilon: t=55 \pm 3{ }^{\circ} \mathrm{C}, \tau=15$ год та концентрація ферментного препарату 1,5\% до маси пюре з м'якоті гарбуза. Досягнуто зростання вмісту РП (розчинного пектину) у 3,5-3,7 раза порівняно з початковим його вмістом. Надано рекомендації щзодо використання ферментованого напівфабрикату з м'якоті гарбуза в подальшому в складі продукту з підвищеним вмістом пектину.

Ключові слова: пюре з м'якоті гарбуза, температура, час, фермент мікробного походження, пектин.

Постановка проблеми. Гарбуз вважається однією з найдавніших баштанних культур. У плодової м'якоті цієї баштанної культури містяться цукри, пектин, солі калію, кальцію, магнію, заліза, вітаміни С, В1, В2, В6, В9, РР і провітамін А. Велика кількість пектину має особливо позитивну дію при запаленні товстого кишечника. Відома здатність пектинових речовин виводити з організму токсичні речовини та радіоактивні метали [1].

Площі вирощування гарбуза в промисловому секторі овочівництва України за останні 15 років зросли більш ніж у 3 рази і становлять 25 тис. га, а обсяги зібраного врожаю сумарно досягають 744,4 тис. тонн [2]. Вирощування гарбузів в Україні здійснюється з метою подальшої їх промислової переробки для отримання олії та шеретованого насіння гарбуза. М'якоть, після того як виберуть насіння, 
використовують на корм худобі і для силосування. Загалом лише 28\% загального об'єму м'якоті гарбуза направляється на подальшу переробку [3]. Питанням переробки гарбуза займалися С.О. Белінська, А.В. Матора, О.Г. Шкодина, В.С. Коршунова, В.Ф. Вінницька, Г.К. Селезньова та ін. [4].

Серед промислових способів Л.П. Малюк і Г.В. Фетісова для переробки значних об'ємів м'якоті гарбуза пропонують спосіб виготовлення овочевих паст з гарбуза та аронії. Запатентовані способи виробництва характеризуються складним багатоступінчастим технологічним процесом, що робить непридатними дані технології для впровадження. Серед інших відомих нині способів переробки м'якоті гарбуза є спосіб комплексної переробки, що передбачає його підготовку, різання, видалення насіння, бланшування м'якоті, іiі протирання і гомогенізацію з отриманням соку. Одержуваний за описаною технологією гарбузовий сік не користується широким попитом через притаманний специфічний запах вареного гарбуза.

Серед способів переробки м'якоті гарбуза на виробництвах непромислових масштабів, тобто в закладах ресторанного господарства, застосовують консервування шляхом заморожування, виробництво паст, кремів і тістових напівфабрикатів з м'якоттю гарбуза. Запатентовано десерт гарбузово-динний заморожений, пиріг гарбузовий «Сонечко» та «Берлінське чудо» 3 начинкою на основі пасти з гарбуза, заварний виріб з гарбузово-топінамбуровою начинкою тощо [5]. Широко відомим є використання м'якоті гарбуза як джерела пектину в кулінарних і кондитерських стравах. Проте відомі технології передбачають використання температурної обробки м'якоті при $\mathrm{pH} \approx 4$, що досягається додаванням органічних кислот. Це зумовлює внесення значної кількості підсолоджувачів і впливає на смак виробів. У зв'язку з цим пошук оптимальних параметрів обробки м'якоті гарбуза з метою отримання універсального напівфабрикату з підвищеним вмістом пектину для використання у складі кондитерських і кулінарних виробів є актуальним.

Одним $з$ ефективних способів вирішення збереження біологічно активних речовин рослинної сировини є застосування ферментних препаратів (ФП), а також культивування мікроорганізмів. Попередніми дослідженнями доведено, що при обробці гарбуза ферментними препаратами спрямованої дії кількість пектину збільшується. Питанню ферментативної обробки м'якоті гарбуза присвячено наукові дослідження О.А. Маркіної, А.В. Матори, О.Г. Шкодіної, В.Е. Коршунової та ін. Застосування ферментів, продукованих мікроорганізмами роду Bacillus, на думку цих науковців, дає змогу збільшити вихід пектину на 30-35\% при збереженні екологічності процесу його отримання. Відомим технічним рішенням є спосіб отримання пектину, що полягає в культивуванні на субстраті мікроорганізмів роду Bacillus, 3 подальшим змішуванням гідролізату з рослинною пектиновмісною сировиною, екстрагуванням суміші та виділенням розчинного пектину. В той же час, зважаючи на високий ступінь екологічності процесу, доцільним $є$ ферментування рослинної сировини без видалення пектину з їі складу, а з використанням в подальшому як продукту з підвищеним вмістом пектину [6].

Тож перспективним є напрям переробки вторинної рослинної сировини гарбуза, з метою отримання продукту з високим вмістом пектину. 
Метою статті є дослідження кінетики ферментолізу пектинових речовин м'якоті гарбуза під дією ферментного препарату спрямованої дії Ветом 1.1 залежно від впливу технологічних факторів.

Матеріали і методи. Для дослідження було обрано гарбуз мускатний Cucurbita moschata Duch. столового сорту Баттернат (Butternut), що $є$ широко розповсюдженим у торговельній мережі й володіє відмінними органолептичними властивостями. До зразків гарбуза застосовано такі температурні режими зберігання: $+8 \ldots+10^{\circ} \mathrm{C}$ та $-16 \ldots-18^{\circ} \mathrm{C}$. Дослідження проводились на шостий місяць (березень) після збору врожаю 2017 року. Підготовка зразків пюре гарбуза до контакту з ферментним препаратом здійснювалась за технологією [7]. Зразки пюре з гарбуза піддавались спрямованій дії препарату Ветом 1.1 на основі ферменту, продукованого бактеріями роду Bacillus subtilis. Внесення ферментного препарату, що існує у формі порошку, здійснювалось шляхом його розчинення в рідкій фракції, відділеній самовільно при приготуванні пюре з гарбуза, з подальшим з'єднанням рідкої та твердої фракцій.

Вміст розчинного пектину в дослідних зразках визначали стандартним кальцій-пектатним методом [8]. Для обробки отриманих результатів експериментальних досліджень використано статистичні та математичні методи обробки даних.

Викладення основних матеріалів дослідження. Варіабельність параметрів отримання продукту з підвищеним вмістом пектину визначає необхідність дослідження кінетики ферментолізу пектинових речовин залежно від температури зберігання плодів і температурного режиму процесу ферментолізу, кількості внесеного ферментного препарату Ветом 1.1.

На першому етапі досліджень було визначено, що в процесі зберігання плодів гарбуза різних сортів вміст протопектину знижується, а вміст розчинного пектину зростає. Так, при зберіганні плодів гарбуза різних сортів загальна кількість пектинових речовин суттєво знижується від першопочаткового вмісту за різних температур зберігання. Тому неушкоджені плоди гарбуза рекомендується зберігати за температури $+2 \ldots+4^{\circ} \mathrm{C},+8 \ldots+10^{\circ} \mathrm{C},+16 \ldots+18^{\circ} \mathrm{C}$, в той час як плоди з порушеною цілісністю зовнішньої оболонки - за $-18 \ldots-16^{\circ} \mathrm{C}[9]$.

Динаміка зміни загальної кількості пектинових речовин у плодах гарбуза досліджуваного помологічного сорту Баттернат (Butternut) за означених температурних режимів зберігання наведено у табл. 1 .

Таблиия 1. Загальний вміст пектинових речовин за різних режимів зберігання

\begin{tabular}{|c|c|c|c|c|c|}
\hline \multirow{2}{*}{ Сорт } & Час аналізу & \multicolumn{4}{|c|}{ Режим зберігання } \\
\cline { 3 - 6 } & $+2 \ldots+4^{\circ} \mathrm{C}$ & $+8 \ldots+10^{\circ} \mathrm{C}$ & $+16 \ldots+18^{\circ} \mathrm{C}$ & $-18 \ldots-16^{\circ} \mathrm{C}$ \\
\hline $\begin{array}{c}\text { Гарбуз мускатний сорту } \\
\text { Баттернат (Вutternut) }\end{array}$ & Березень & 1,18 & 1,29 & 1,20 & 0,79 \\
\hline
\end{tabular}

Як видно з табличних даних, спостерігається зростання кількості розчинного пектину за температурного режиму зберігання $+8 \ldots+10^{\circ} \mathrm{C}$, що пояснюється переходом протопектину в форму розчинного пектину. В той же час за низькотемпературного зберігання пектин переходить у розчин міжклітинної рідини і видаляється в процесі розморожування. Так, зразки м'якоті гарбуза, які підлягали зберіганню за низьких температур, мали нижчий результуючий вміст пектинових речовин на $40-47 \%$, ніж при зберіганні за $+8 \ldots+10^{\circ} \mathrm{C}$. 
У зв'язку з вищевикладеним на першому етапі досліджень визначено дію ферментного препарату на дослідні зразки гарбуза, що зберігалися за температури $+8 \ldots+10^{\circ} \mathrm{C}$ та $-18 \ldots-16^{\circ} \mathrm{C}$. Кількість внесеного препарату була постійною і дорівнювала $1,5 \%$, що входить в інтервал за рекомендаціями виробника $1-3 \%$. Тривалість процесу становила 3 год. Динаміка накопичення РП в м'якоті гарбуза залежно від різних температурних режимів зберігання та за різних температур процесу ферментолізу наведено на рис. 1 .

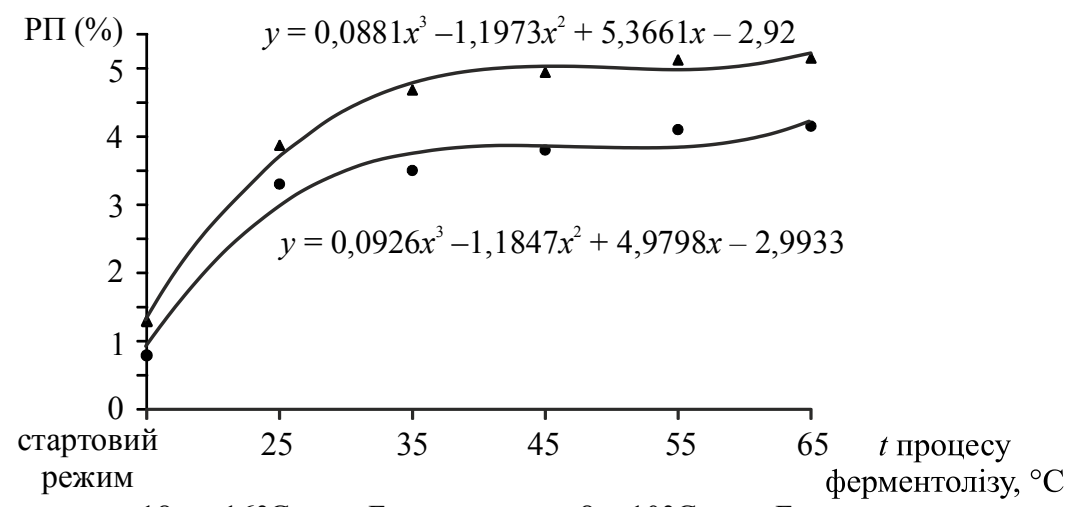

- $-18 \ldots-16^{\circ} \mathrm{C}$ сорт Баттернат

- $8 \ldots 10^{\circ} \mathrm{C}$ сорт Баттернат

\section{Рис. 1. Динаміка накопичення РП у м'якоті гарбуза залежно від температур зберігання і ферментолізу}

На рис. 1 поліноміальна крива кореляції характеризує зростання вмісту РП залежно від температурних параметрів зберігання та ферментолізу. За результатами проведених досліджень встановлено, що вміст розчинного пектину (РП) 3 підвищенням температури процесу ферментолізу рівномірно збільшується в обох зразках гарбуза. Початкова різниця вмісту РП становить $63 \%$ в зразках гарбуза сорту Баттернат за температур $+8 \ldots+10^{\circ} \mathrm{C}$ порівняно 3 температурним режимом $-18 \ldots-16^{\circ} \mathrm{C}$. Так, показники вмісту РП в зразках гарбуза, що зберігався за температур $+8 \ldots+10^{\circ} \mathrm{C}$ при $25^{\circ} \mathrm{C}, 35^{\circ} \mathrm{C}, 45^{\circ} \mathrm{C}$ та $55^{\circ} \mathrm{C}$ вищі на $17 \%, 34 \%, 30 \%$ та $25 \%$ відповідно. Інактивація ферментного препарату відбувається за температури вище $55^{\circ} \mathrm{C}$. Термічна обробка продукту за температури $65^{\circ} \mathrm{C}$ супроводжується інтенсивним випаровуванням вологи, згущуванням продукту, а зростання вмісту РП пов'язано також зі зменшенням об'єму вихідного продукту. Таким чином встановлено, що раціональним температурним режимом ферментолізу для обох зразків м'якоті гарбуза $\epsilon$ температура $55 \pm 3^{\circ} \mathrm{C}$. Виявлено, що при обробці ферментним препаратом зразків м'якоті гарбуза суттєво впливає на вміст РП не тільки температурний режим ферментолізу, а й температурний режим зберігання плодів.

На другому етапі досліджень визначено вплив тривалості процесу $\tau($ год) ферментолізу за визначених режимів $\left(C=1,5 \% ; t=55 \pm 3^{\circ} \mathrm{C}\right)$ на динаміку накопичення РП (\%) у м'якоті гарбуза (рис. 2). Для визначення меж активності ферментного препарату обрано тривалість дослідження в діапазоні $1 . . .24$ год. Дія ферментного препарату спрямовувалась на дослідні зразки м'якоті гарбуза, що зберігалися при температурі $+8 \ldots+10^{\circ} \mathrm{C}$ та $-18 \ldots-16^{\circ} \mathrm{C}$. 


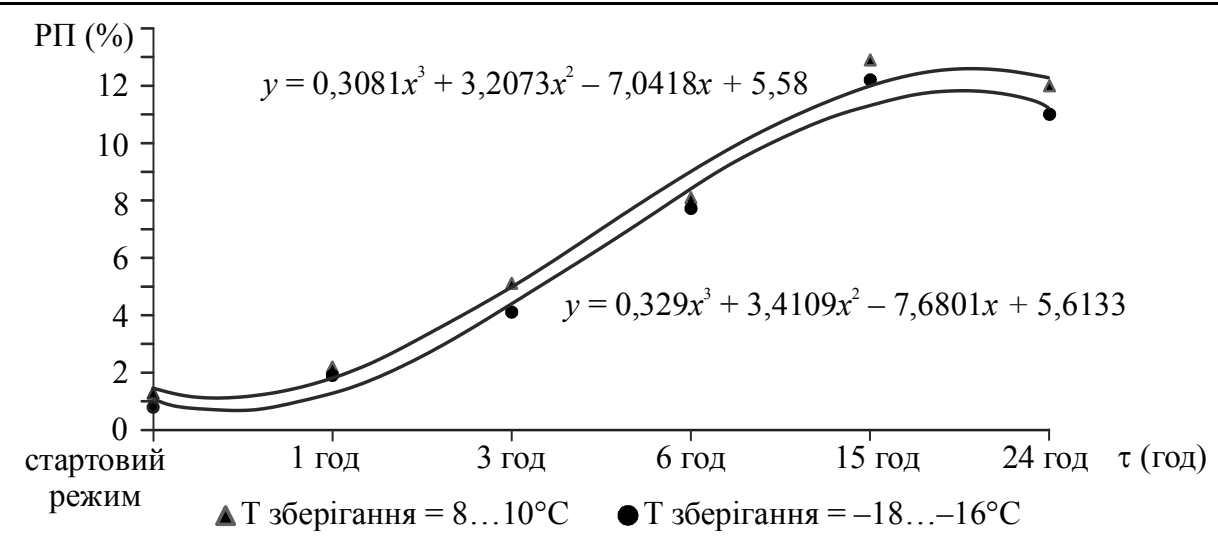

Рис. 2. Динаміка накопичення РП у м'якоті гарбуза залежно від тривалості ферментолізу

Як видно з рис. 2, графік процесу ферментолізу є нелінійним. Результати, отримані після контакту продукту з ферментним препаратом протягом 1 год, свідчать про неефективність короткотривалого впливу. За збільшення тривалості ферментативного процесу до 24 год спостерігається зменшення вмісту виявленого РП в досліджуваному продукті, що пояснюється швидким виродженням мікроорганізмів ферментного препарату Ветом 1.1 та супроводжується видаленням метоксильних груп 3 молекули пектину з переведенням останнього в пектинову кислоту, що не має желюючих властивостей. Тривалість ферментолізу 15 год, за якого поліноміальна крива має максимальне значення, визначено як раціональну.

На наступному етапі дослідження визначено, що раціональну концентрацію внесеного ферментного препарату Ветом 1.1 за сталих значень $\mathrm{t}=55 \pm 3^{\circ} \mathrm{C}$ та $\tau=15$ год. Результати дослідження представлені на рис. 3 .

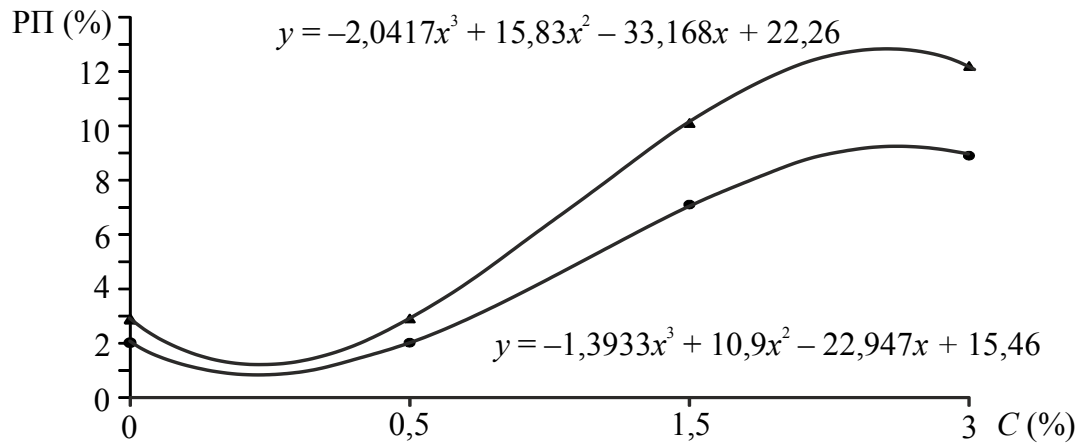

$\Delta \mathrm{T}$ процесу $=55^{\circ} \mathrm{C}, \mathrm{T}$ зберігання $=8 \ldots 10^{\circ} \mathrm{C}$

- $\mathrm{T}$ процесу $=55^{\circ} \mathrm{C}$, Т зберігання $=-18 \ldots-16^{\circ} \mathrm{C}$

Рис. 3. Динаміка накопичення РП у м'якоті гарбуза залежно від концентрації ферментного препарату

Як видно з рис. 3, суттєве зростання вмісту розчинного пектину спостерігається при концентрації внесеного ферментного препарату в кількості 1,5\%. Відмічається зростання вмісту РП у $3,5-3,7$ раза порівняно $з$ початко- 
вим його вмістом в обох зразках. Використання ферментного препарату в кількості менше $1,5 \% \in$ недоцільним і характеризується незначним зростанням вмісту РП в $1,1-1,2$ раза. Внесення препарату в кількості $3 \%$ характеризується зростанням вмісту РП у 4,2-4,4 раза, проте супроводжується значним зростанням собівартості.

\section{Висновки}

Отже, раціональними параметрами процесу $\epsilon: 55 \pm 3^{\circ} \mathrm{C}, 15$ год, $1,5 \%$. Отримані тенденції підтверджують, що за збільшення тривалості ферментолізу, навіть за наявності несприятливих стартових характеристик продукту, спостерігається суттєве збільшення вмісту РП у досліджуваних зразках пюре 3 гарбуза. Встановлено, що на вміст РП в вихідному продукті впливають режим зберігання та сортність гарбуза. Визначено, що низькотемпературне зберігання суттєво сповільнює процес утворення РП та негативно впливає на його вихід. Саме тому в цьому випадку ферментативна обробка м'якоті гарбуза виявляється найбільш доцільною, адже після вибирання насіння 3 плода гарбуза зовнішня його оболонка пошкоджується, що унеможливлює подальше зберігання плода гарбуза за інших температурних режимів. У той же час, зважаючи на ефективність дії ферментного препарату на зразки гарбуза, що зберігався за $+8 \ldots+10^{\circ} \mathrm{C}$ та відмінні органолептичні показники, стає можливим і доцільним застосування препарату до плодів одразу після збирання.

\section{Література}

1. Барахаева Л.П. Химический состав и технологические свойства тыкв, кабачков и патиссонов: Автореф. дисс. канд. техн. наук / МИНХ. - Москва, 1983. — 22 с.

2. Семен O.T. Агроекологічне обгрунтування елементів технології вирощування плодів гарбуза мускатного для дієтичного харчування в умовах півдня України: Дис. ... канд. с.-г. наук. - Харків, 2015. - 235 с.

3. Діденко В.П. Сучасний стан і перспективи забезпечення населення України продукцією баштанництва / В.П. Діденко, О.С. Шабля // Овочівництво і баштанництво. 2004. — № 49. - C. $80-85$.

4. Тимчак В.С. Ефективність інновацій комплексного використання відходів харчової промисловості: Дис. канд. економічних наук. - Житомир, 2016. — С. 41-43.

5. База патентів України UAPATENTS.COM [Електронний ресурс]. — Режим доступу : http://uapatents.com/ .

6. Пат. RU 2059385 C1, МПК6 A 23 L 1/0524, C 08 B 37/06. Способ получения пектина / А.В. Матора, О.Г. Шкодина, В.Е. Коршунова, Н.М. Птичкина // Опубл. 10.05.96. Бюл. № 13.

7. Юдіна T.I. Наукове обгрунтування технологій структурованої кулінарної продукції 3 використанням концентратів сколотин: Дис. ... докт. техн. наук. - Київ, 2016. - 302 с.

8. Арасимович В.В. Методы анализа пектиновых веществ, гемицеллюлоз и пектолитических ферментов в плодах / В.В. Арасимович, С.В. Болтага, Н.Н. Пономарева. Кишинев : Академия наук СССР, 1970. - $84 \mathrm{c}$.

9. Колтунов В.А. Зберігання гарбузових плодів: наук. вид. / В.А. Колтунов, Л.М. Пузік. - Харків : Харк. нац. аграр. ун-т ім. В.В. Докучаєва, 2009. - 365 с. 